\title{
Corruption in Afghanistan: an Experience for Ukraine
}

\author{
Zaid Rahmani
}

BA student at International Law, Institute of International Relations, Taras Shevchenko

National University of Kyiv (Kabul, Afghanistan)

E-mail: zaidrahmani777@gmail.com

\section{Vadym Tytarenko}

PhD, Assistant Professor, Taras Shevchenko National University of Kyiv (Kyiv, Ukraine) E-mail: tytarenko.vadym@gmail.com

ORCID: 0000-0001-9251-8859

The problem of corruption is one of the most urgent and important to solve for present Ukraine. Corruption is considered to be one of the main reasons for the lack of prosperity in Ukraine as well as political instability. Despite the numerous governmental attempts to fight against the corruption its level unfortunately still increases. Effective strategies search in resolving this problem appears as most relevant and necessary today. Ukrainian authority and anti-corruption organizations can effectively use the passive and active experience of other countries that have the same problem in order to prevent or stop the facts of corruption. Unfortunately, the Islamic Republic of Afghanistan is a "superlative" in some corruption statics in the world. The permanent long time struggle against a corruption under the conditions of permanent war allowed to collect a large experience that must be comprehended by other countries with similar problems.

This paper targets to observe and generalize some crucial corruption statistics and significant anticorruption steps of Afghans in order to contribute to the formation of future successful anti-corruption strategies of Ukraine. policy

Key Words: Afghanistan, Ukraine, corruption, anti-corruption, public administration, Ukrainian

Received May 30, 2018; accepted June 15, 2018

Ukrainian Policymaker, Volume 2, 2018: 27-32

DOI: $10.29202 /$ up/2/4

(C) Rahmani, Zaid, 2018
(C) Tytarenko, Vadym, 2018 


\section{Introduction}

For some years Afghans have been reporting in surveys that corruption is a daily problem. The United Nation Assistance Mission to Afghanistan's previous report on corruption detailed the pervasiveness of the phenomenon. Corruption has a concrete impact on all citizens of Afghanistan, who are required to pay bribes in nearly every aspect of daily life, and who suffer from inequities in economic and employment opportunities as a result of widespread nepotism and patronage. More fundamentally, the perception of endemic corruption - based, unfortunately, on real experiences as a recent survey 3 demonstrated — has undermined public confidence in Government institutions, which has, in turn, hindered the pursuit of wider objectives, such as domestic political stability, electoral preparations, and a credible peace process with the armed opposition.

Ascertain emblematic instances have shown, corruption in Afghanistan is massive (the nearly one billion dollars stolen in the Kabul Bank case), inhumane (the treatment of wounded soldiers in the Military Hospital case), and brazen. The degree of corruption, and the apparent lack of concern by those committing it that there will be any consequences - legal, financial, or even in terms of social opprobrium - to their often despicable actions, has surprised even those with the most realistic perspectives on the challenges of post-conflict state-building. Fighting corruption is also a condition for creating an appropriate investment climate.

The question is, therefore, how has it come to this state? While some have argued that lowlevel corruption was always present in Afghanistan, it is clear that the decades of resistance and civil war created a culture of impunity and left a legacy of political actors who wield informal power, are often disposed to act at the behest of foreign financial backers, and are skilled at resisting formal authorities.

This historical lens should also help us understand what may be unique about Afghanistan's corruption problem. The problem of corruption in Afghanistan can be seen as materially different from that in other countries, even other countries emerging from conflict, in that it is characterized more by a lack of public institutions than the abuse of public institutions by private rent-seekers. The weakness of public institutions is rooted in Afghanistan's preconflict legacy of weak statehood, as well as decades of war which, as described above, created a political economy that privileged and preserved informal power-holders who have been able to resist attempts to formalize and legalize the exercise of power. Decades of war also fundamentally transformed society, weakening the traditional norms that once might have prevented the sorts of accumulation of wealth and abuse of power that Afghanistan has witnessed since the new political order was established in 2001, and developing psychologies of scarcity and uncertainty.

This coupled with an international effort that has treated state-building generally and anticorruption in particular in a haphazard way has created the seemingly intractable problem we face today. As much as the international community sees itself as a driver of anti-corruption efforts, it cannot overlook that, as Vanda Felbab Brown has recently written, the international community "has oscillated between tolerating corruption for the sake of other goals, battlefield shortcuts, and exigencies (with the justification that Afghans are used to corruption anyway) and confronting it head-on but with little effectiveness. 


\section{Corruption and Afghan's political authority}

The two leaders of Afghanistan's post-2014 National Unity Government, President Ashraf Ghani and Chief Executive Abdullah Abdullah, are not only aware and concerned about the problem but separately campaigned on anti-corruption platforms. Afghanistan's slight rise in its Transparency International score from 8 in 2012 to 15 in 2016 and 2017 - although the country still ranks as the fourth most corrupt country in the world is evidence that some of their efforts are bearing fruit. The leaders of the National Unity Government should be congratulated for the undertaking, in particular, the drafting of a national anti-corruption strategy, which is discussed in this report. Furthermore, the Government and its representatives at various levels engaged forthrightly with a draft of this report, seeking to ensure accuracy and context but not trying to hide deficiencies in the anti-corruption effort. The details in this report describe some of these efforts, but also make clear both that much more needs to be done and that the problem cannot be addressed by the executive alone. An insufficiently noted irony is the millions that the international community pays to hold credible and democratic elections for a parliament that, as soon as it is elected, is often ignored. As this report describes, Afghanistan's legislature is part of the corruption problem and has, for the most part, avoided trying to be part of the solution. Nonetheless, the credibility of the commitment of the Government to see through reforms is an unavoidable pre-requisite for the success of anti-corruption efforts. In this, the current Afghan Government - though it will face re-election next year — is not only far superior to its predecessor, but also to many other countries that are both less corrupt but less committed to dealing with the problem.

For many countries, corruption is manageable if unfortunate, and bribes are seen as an unofficial tax on Government services. If UNAMA is paying much attention to this problem in Afghanistan, it is because the current situation is not manageable; addressing corruption is simply essential for national survival. On a more pragmatic level, a failure to make progress against corruption will discourage already-fatigued donors from financing the Afghan state. If this financing has, as this report details, contributed more than it should have to the problem of corruption, it is also essential for the survival of the State and its efforts to root out corruption.

The most known corruption case of the recent times is Kabul Bank financial swindle that was organized under a supervision of President Hamid Karazi administration. Several responsible top managers (Sherkhan Farnood, Mohammed Fahim and others) who were in charge of this financial institution were stealing and spending about 1 billion US dollars for individual needs (luxurious lifestyle etc.) as well as loaning money unofficially to their friends, family mates and members and other people from President Hamid Karzai and Mahmood Karzai surrounding. Due to the financial reports, the Afghan government collected only 180 million dollars of 980 million illegal loans.

Numerous surveys report that unemployment, corruption and insecurity are the most commonly spread and urgent problems of Afghans everyday life. "Surveys of Afghan opinion repeatedly put corruption as the third biggest problem after insecurity and unemployment, with the notable exception of the United Nations Office on Drugs and Crime (UNODC) 2010 survey that places it as the biggest problem of Afghans" [Torab, 2012: 3]. Other important figures reflected in the Asia Foundation reports are the following. "Administrative corruption is perceived as the second most important failure (25\%) of the government after insecurity $(32 \%)$. This is a significant improvement over the results of the 2010 Asia Foundation survey, in which failure to fight corruption was tied, at $30 \%$, with insecurity in being cited 
as the biggest failure of the Afghan government. Nonetheless, there is little change in citizen perceptions of their government actually tackling corruption, and the gap is striking between areas of perceived government success, such as education $(85 \%)$ and poor perception of Afghan government success in fighting corruption (35\%)"[Torab, 2012: 3].

Different international organizations report that corruption in Afghanistan is no longer a serious disease of the social system, but the social system itself.

The Agency for International Development (USAID) emphasized in 2013 that "Corruption in Afghanistan has become entrenched and extremely well-organized through patronage groups, imposing a staggering impact on the daily lives of Afghans. Afghanistan is seen to be a 'bazaar economy' where every government service is subject to illicit bargaining and payment" [USAID, 2013: 9].

The most commonly spread kinds of corruption activity today in Afghanistan are casual bribes (demanding and offering in private and public spheres), graft, nepotism, illegal land transfer. The Ukrainian corruption reality looks almost similar to Afghan one. The corruption is present on the all possible levels of social affairs.

It was estimated that more than half of the annual state customs income is lost because of the illegal corruption goods transfer.

Parag R. Dharmavarapu is his paper devoted to the corruption in the post-conflict Afghanistan, numerous examples of corruption acts. "What is extremely disconcerting about corruption in Afghanistan, is not simply the number or value of bribes that take place; instead, it is the endemic nature of corruption within the Afghan government... Police officers extort goods from shopkeepers, levy taxes on vehicles at highway checkpoints, and impose fines on individuals unable to produce proper identification documents. Some of them on the top turn a blind eye to or even collude with criminals and insurgents, while mid- to high-level police officials collaborate with criminals in smuggling, kidnapping for ransom and other illegal activities, collecting thousands of dollars in the process" [Dharmavarapu, 2015].

\section{Afghanistan's and Ukraine's rankings in the world corruption statistics}

"Transparency International's" annual "Corruption Perceptions Index" ranks Afghanistan as the $4^{\text {th }}$ most corrupt country in the world. Previous positions in the ranking obtain Syria, South Sudan and Somalia.

The organization informs that most of the countries on the list show a marginal or a totally absent progress in order to stop corruption. The results reveal that activists and journalists in corrupt countries are permanently in danger because of their professional activity.

The index deals with 180 countries and territories ranking them by the level of public. The index is formed by the feedbacks of experts and businesspeople, using a scale of 0 to 100 , where 0 is highly corrupt and 100 is not corrupt.

Presently, the index revealed that more most of countries (2/3) appear on the level of less than fifty. The middle score is 43 .

In 2017, New Denmark and New Zealand obtain the top positions with the score of 88 and 89. Somalia, Syria and South Sudan are the lowest in the list obtaining following figures: 9 , 14 and12. Afghanistan's score is 15. Sudan and Yemen are on the positions of 17 and 16. The most interesting fact is that North Korea has a better rank that Afghanistan - 17. By far the most no-corrupted region is Western Europe, which has a ratio 66. 
By far the worst region in the matter of corruption in Sub-Saharan Africa (score 32) Central Asia and Eastern Europe (average score 34). Ukraine shows the very poor result in comparison with most of the post-soviet countries. Ukrainian score in the rank is 30 .

After 2012, some states crucially improved their result in the matter of score. Ukraine, unfortunately, could add only 4 points to its general score. Afghanistan changes were also not so high in the matter of points, but in the general amount, it showed the double progress: from 8 to 15 . Some of the countries showed negative tendency and no development at all (Syria, Yemen and Australia).

We must assert due to the mentioned report that Afghan authority's struggle against the corruption reveals its ineffectiveness especially in the targeting of the United Nations' Sustainable Development Goals (SDGs).

SDGs, which was accepted by 193 nations aspire to stop poverty, defend the Earth and guarantee prosperity for everybody by 2030. established a series of different aims for governments in order to develop the level of justice, sustainable development, healthcare, economic growth, clean energy.

Struggle against corruption is a part Goal 16 of SDG, which is provided, gives a hope for further sustainable development.

One of the most important analytical sources which can give a lot of significant instructions for Afghanistan and other corrupted countries is a comprehensive report named "Policy, SDGs and Fighting Corruption for the People». This report provides an assessment of the progress of Afghanistan in obtaining the anti-corruption aims. The report provides an evaluation of the states' contribution to the salvation of three key "Goal 16" connected with the corruption:

Target 16.4 on illegal money and weapons flows, organized crime etc.

Target 16.5 on corruption activity and bribes.

Target 16.10 on informational freedom and common freedoms.

In experts' opinion, Afghanistan requires a responsible and anticorruption active government. Such authority is one of the necessary conditions for the state to meet SDG commitments to stop poverty, to defend peace and guarantee the justice implementation.

Afghanistan and Ukraine are the countries that have adopted the SDGs; nevertheless, struggle against corruption in case of Afghanistan has not fully begun and in case of Ukraine mostly is declarative but not real. Anticorruption strategies of Afghanistan have not been widely publicly discussed. The plan of Sustainable Development Goals still remains the matter of future. The author is sure that creation of such a plan has to be completed first and its implementation is done as well. The accomplishment of the Goal 16 targets and other SDG tasks will definitely help the state to overcome a present deep crisis.

An interesting anticorruption project was held in Kyiv "Corruption Park" [Corruption Park, 2018]. It is a project especially developed to inform a society about the drawbacks of the corruption and the effective ways of the corruption fight.

\section{Conclusions}

Afghanistan and Ukraine both suffer from corruption and other illegal power and finances connected activity. The corruption is spread on all levels of the social and political life of the states (road police, public administration, education of all levels, the legal system, military administration, top governmental authority etc.) Consequently, this corruption problem negatively impacts national economies and affects the general prosperity of a population 
[Bazaluk, 2016; Bazaluk \& Blazhevych, 2016].

In accordance with a mentioned above situation the following solutions for Afghanistan can be proposed as an attempt to solve the problem: a) reduce bureaucracy at all levels of public administration. All the administrative personnel have to be carefully selected by the specialized organization s with an assistance and consultation of international organizations; b) accept of international anticorruption aid programs as well as reform of the legislation that regulates financial flows; c) to create the conditions for cooperation with an Afghan society in order to change the perspective on the corruption and develop the civil society, using the educative technologies.

The Afghan corruption and anti-corruption struggle experience can be useful for Ukraine to avoid all negative drawbacks of postwar recovery. Ukraine is now higher in the international corruption ranks than Afghanistan, but paying no attention to the key experience of other countries can make the situation worse.

Fighting against corruption can provide a lot of advantages for the sustainable development of both Afghanistan and Ukraine. That is why both countries must focus all possible attention to resolve this crucial problem and obstacle to the prosperity.

\section{[D] References}

Assistance for Afghanistan's anti-corruption authority. (4a) project final report. USAID. November 15, 2013. Retrieved from https://pdf.usaid.gov/pdf_docs/PA00JP3T.pdf.

Bazaluk, Oleg. Corruption in Ukraine: Rulers' Mentality and the Destiny of the Nation, Geophilosophy of Ukraine. Cambridge Scholars Publishing, 2016.

Bazaluk, Oleg, and Tamara Blazhevych. The Image of an Ideal Ukrainian Politician. Ukrainian National Idea. Future Human Image. 3 (6), 2016: 24-30.

Coleman, B. B., Major. The Impacts of corruption on economic development in Afghanistan: A study of the effects of nepotism and bribery (Unpublished master's thesis). U.S. Army Command and General Staff College. Retrieved June 1, 2015, from www.dtic.mil/dtic/ tr/fulltext/u2/a557232.pdf.

Corruption park. First interactive project about corruption and corruption fight. Kyiv 2018. Retrieved from: http://corruption-park.com/

Dharmavarapu, Parag. R. Corruption and Graft in Post-Conflict Afghanistan. Inquiries Journal / Student Pulse, 7(07). 2015. Retrieved from http://www.inquiriesjournal.com/ $\mathrm{a} ? \mathrm{id}=1057$

Goldstein, Joseph. Police force in Afghanistan is studied for ties to Taliban. The New York Times. Feb. 8, 2015, from http://www.nytimes.com/2015/02/09/world/asia/policeforce-in-afghanistan-is-studied-for-ties-to-taliban.html.

People: a civil society report on Afghanistan's sustainable development goals. Retrieved from https://www.transparency.org/whatwedo/publication/policy_sdgs_and_fighting corruption_afghanistan_a_civil_society_report.

Torab, Yama. The growing challenge of corruption in Afghanistan. Reflections on a Survey of the Afghan People, Part 3 of 4. Occasional paper, №. 15, JULY 2012. Retrieved from https:// asiafoundation.org/resources/pdfs/FNLcorruptionchapterOccasionalPaperJuly30.pdf

Zyck, S. Corruption \& Anti-Corruption Issues in Afghanistan. Civil-Military Fusion Centre, 7-7. Retrieved June 1, 2015, from http://reliefweb.int/sites/reliefweb.int/files/resources/ CFC-Afghanistan-Corruption-Volume-Feb2012.pdf 